\title{
EVALUATION OF Lactobacillus plantarum AND Lactococcus lactis ISOLATED FROM DUCK EXCRETA AS POTENTIAL PROBIOTICS FOR CHICKEN NUTRITION
}

\author{
Dini Dwi LUDFIANI 1 , Widya ASMARA ${ }^{2} \bowtie$, Agnesia Endang Tri Hastuti WAHYUNI ${ }^{2}$, Pudji ASTUTI ${ }^{3}$, M. Th. \\ Krisdiana PUTRI ${ }^{4}$, and Nur Fathurahman RIDWAN5 \\ ${ }_{1}^{1}$ Student in Faculty of Veterinary Medicine, Universitas Gadjah Mada, Jalan Fauna Nomor 2 Karangmalang, Yogyakarta 55281, Indonesia \\ ${ }^{2}$ Department of Microbiology, Faculty of Veterinary Medicine, Universitas Gadjah Mada, Jalan Fauna Nomor 2 Karangmalang, Yogyakarta 55281, Indonesia \\ ${ }^{3}$ Department of Physiology, Faculty of Veterinary Medicine, Universitas Gadjah Mada, Jalan Fauna Nomor 2 Karangmalang, Yogyakarta 55281 Indonesia \\ ${ }^{4}$ Department of Veterinary Public Health, Faculty of Veterinary Medicine, Universitas Gadjah Mada, Jalan Fauna Nomor 2 Karangmalang, Yogyakarta 55281 Indonesia \\ 5Research Center for Biotechnology, Graduate School, Universitas Gadjah Mada, Jalan Teknika Utara, Caturtunggal, Yogyakarta 55281 Indonesia \\ Email: wied_as@ugm.ac.id; (D) ORCiD: 0000-0001-6386-8892 \\ Supporting Information
}

ABSTRACT: Since the antibiotic growth promoters (AGP) were banned, probiotics have become one of the increasingly relevant products to be developed in the poultry industry. Thereafter lactic acid bacteria (LAB) isolated from excreta have the potential as probiotics. The aim of this study was to determine the potential probiotic properties of Lactobacillus and Lactococcus isolated from duck excreta. The experiment was conducted in the following two processes, in vitro and in vivo. Based on identification with API 50CHL and 16s rRNA, LAB isolated confirmed Lactobacillus plantarum (L. plantarum) and Lactococcus lactis (LC. lactis). The strains showed tolerance to variation of $\mathrm{pH} 2.0$ to 5.0 , and level bile salt 0.05 to $0.30 \%$; the ability of intestinal adhesion and antibacterial activity against Escherichia coli. The strain was safe to use as a probiotic because is negative for hemolytic activity and high sensitivity to antibiotics. In a In vivo study, a total of 100 Lohmann broilers (7-day-old) were divided into 4 treatment groups included of control (PO), $L$. plantarum BJ3 $10^{7} \mathrm{cfu} /$ bird (P1), Lc. lactis K5 $10^{7} \mathrm{cfu} /$ bird (P2), and L. plantarum BJ3 + Lc. lactis K5 $10^{7}$ $\mathrm{cfu} /$ bird (P3) and received probiotic as orally. The result showed probiotic supplementation affected growth performance of broilers. Probiotic supplementation reduced feed intake (FI) during experimental period $(p<0.031)$, but the feed conversion ratio (FCR) and body weight gain (BWG) were not affected. The P2 group showed the lowest FI. In conclusion, L. plantarum BJ3 and Lc. lactis K5 isolated from duck excreta can be considered as probiotics for chicken nutrition.

Keywords: Antibacterial activity, Dietary supplement, Lactobacillus, Lactococcus, Probiotic.

\section{INTRODUCTION}

Since the antibiotic growth promoters (AGP) were banned, probiotics have become one of the increasingly relevant products to be developed in the poultry industry. Probiotics can be supplemented orally, added to the diet or water (Abd El-Hack et al., 2020). Kook et al. (2019) stated that probiotics are additives that contain non-pathogenic microorganisms, can live and interact with microflora in the digestive tract. Probiotics have pharmacological effects such as antibacterial, anticancer, and anti-mutagenic (Yamazaki et al., 2012; Zitvogel et al., 2017). Probiotics as a feed additive can change the balance of microflora in the intestine, because beneficial intestinal microbes can be suppressed pathogenic bacteria and reduce the possibility of disease infection and also can increase nutrient absorption (Yadav and Jha, 2019). In addition, probiotics are able to increase the production of vitamin $K$, stimulate the immune system, and can detoxify toxins (mycotoxins) in the gastrointestinal tract (Śliżewska et al., 2020).

Probiotics can affect health status because they can stimulate immune responses, inhibit pathogens (Ding et al., 2020; Garcia-Gonzalez et al., 2021), control diarrhea, and reduce cholesterol levels (Ding et al., 2020). Commonly probiotic bacteria belong to the group lactic acid bacteria (LAB); Species of LAB includes genus Lactobacillus, Bifidobacterium, Pediococcus (Alhaag et al., 2019), and Streptococcus are widely used as probiotics (Rahman et al., 2016). The LAB can be obtained from the isolation of various sources, such as processed food products (fermented meat and fish, fermented milk, kimchi, pickles, yogurt), fermented feed (silage), organs of living things (digestive tract), and feces or excreta (Huang et al., 2020; Garcia-Gonzalez et al., 2021).

Isolation of LAB from excreta can reflect the group of bacteria present in the digestive tract (Huang et al., 2020). Among farm animals, ducks are poultry that are susceptible to disease and have good digestibility of fiber feed (Han et al., 2017; Ibrahim et al., 2020). It is suspected that the role of the microbiota in the digestive tract is in helping the absorption of feed nutrients and stimulating the immune response. Previous studies found Lactobacillus sp. as the most 
dominant bacteria isolated from chicken excreta (Yamazaki et al., 2012; Aazami et al., 2015; Robledo-Cardona et al., 2018; Ludfiani et al., 2020).

The aim of this study was to determine the potential probiotic properties of Lactobacillus and Lactococcus isolated from duck excreta for supplementing in poultry diets.

\section{MATERIALS AND METHODS}

The experiment was conducted in the following two processes, in vitro and in vivo;

\section{Isolation LAB}

The LAB used were isolated from duck excreta from different duck farms in Bantul, Yogyakarta, Indonesia. A total of $1 \mathrm{~g}$ duck feces sample was added and diluted in sterile saline solution (0.85\%). Then the suspension was spread on de Man Rogosa Sharpe (MRS) agar containing bromocresol purple (BCP). It was incubated for 48 hours at $37^{\circ} \mathrm{C}$ under anaerobic conditions. The colonies were purified and cultures were stored as culture stock at $-30^{\circ} \mathrm{C}$ in sterile skim milk (10\% W/V: weight/volume) and sterile glycerol (20\% V/V; Volume/Volume) (Brashears et al., 2003).

\section{Morphological, physiological, and biochemical test}

The LAB isolates were identified by morphological tests (Gram staining, motility test, and catalase test) as described by Amaliah et al. (2018). Afterwards the physiological tests were determined by the growth of LAB in MRS broth at 10 , 35 , and $45^{\circ} \mathrm{C}$. The turbidity was observed for 24 hours to 72 hours in each temperature treatment (Thakkar et al., 2015). Growth of LAB in MRS broth at pH 2.0, 3.0, 4.0, and 5.0. The turbidity was observed and the absorbance optical density (O.D.) was read with a spectrophotometer $\lambda=620 \mathrm{~nm}$ (Brashears et al., 2003). Growth of LAB in MRS broth was containing bile salt at $0.05,0.15$, and $0.30 \%$. The turbidity was observed and the absorbance 0.D. was read with a spectrophotometer $\lambda=620 \mathrm{~nm}$ (Gilliland et al. 1985). A biochemical test was carried out using API $50 \mathrm{CHL}$ following the manufacturer's instructions (bioMérieux Co, France) and the color changes were identified using the Apiweb ${ }^{\text {TM }}$ software (Karakas-sen and Karakas, 2018).

\section{Molecular identification of LAB}

The molecular identification of LAB isolates was carried out by 16S rRNA sequence analysis (Nurhikmayani et al., 2019). LAB isolates were centrifuged at $14,000 \mathrm{~g}$ for $1 \mathrm{~min}$, then the supernatant was removed, and the total genomic DNA was extracted using the Presto ${ }^{\text {TM }}$ Mini gDNA bacterial kit (Presto Co, Geneaid). The 16S rRNA was amplified by polymerase chain reaction (PCR) using My Taq HS Red Mix and universal primers 27F (5'-AGAGTTTGATCMTGGCTCAG-3') and 1492R (5'-TACGGYTACCTTGTTACGACTT-3'). The DNA extracts from isolates were mixed with a PCR cocktail (12.5 $\mu \mathrm{L}$ My Taq HS Red Mix 2x, $1 \mu \mathrm{L}$ primers 27F and 1492R with final concentrations of $20 \mu \mathrm{mol} / \mu \mathrm{L}$, and $9.5 \mu \mathrm{L}$ ddH ${ }_{2} \mathrm{O}$ ). The DNA template used was $1 \mu \mathrm{L}$ for each reaction. Pre-denatured PCR at $95^{\circ} \mathrm{C}$ for $1 \mathrm{~min}$, followed by 35 cycles at $95^{\circ} \mathrm{C}$ for $15 \mathrm{sec}$, annealing at $52^{\circ} \mathrm{C}$ for $15 \mathrm{sec}$, extension at $72^{\circ} \mathrm{C}$ for $45 \mathrm{sec}$, and final extension at $72^{\circ} \mathrm{C}$ for $10 \mathrm{~min}$. The PCR products were confirmed by gel electrophoresis on $1.5 \%(\mathrm{w} / \mathrm{v})$ agarose with ethidium bromide. PCR products were sequenced by bi-directional sequencing at Integrated Research and Testing Laboratory (LPPT) Universitas Gadjah Mada. Sequences of bacterial isolates were analyzed using the basic local alignment search tool (BLAST; https://blast.ncbi.nIm.nih.gov/) for the 16S rRNA sequence database (Bacteria and Archaea).

\section{Enzyme activity test}

Enzymatic activity test was carried out using API ZYM following the manufacturer's instructions (bioMérieux Co, France). The color changes were observed and compared with the ZYM API color reference (Karakas-sen and Karakas, 2018).

\section{In vitro adhesion assay}

Adhesion assay was determined as described by Fuller's (1975) method modified Garriga et al. (1998). Chicken epithelial cells were prepared at a concentration of about $8.75 \times 10^{5}$ cells $/ \mathrm{ml}$, and the concentration of LAB cells was about $1.50 \times 10^{8} \mathrm{cfu} / \mathrm{ml}$. The bacterial suspension $(100 \mu \mathrm{l})$ was inoculated into $400 \mu \mathrm{l}$ of the epithelial cell suspension. It was then incubated for $30 \mathrm{~min}$ at $37^{\circ} \mathrm{C}$ in a shaking water bath. Adhesions were observed with a microscope.

\section{Antibacterial activity assay}

The antibacterial activity of LAB was determined by the disc diffusion method (Karimi et al., 2018). The bacteria that be used in the antibacterial activity test is Eschericia coli. Tetracycline antibiotics were used for comparison.

\section{Antibiotic susceptibility assay}

The antibiotic susceptibility of LAB was tested against five antibiotics (ampicillin, bacitracin, erythromycin, streptomycin, and tetracycline) by using the antibiotic disc diffusion method on MRS agar plates as described by Goswami et al. (2017). The diameter of the inhibition zone was measured and interpreted according to the criteria in Table 1. 
Table 1 - Criteria for the diameter of the antibiotic inhibition zone

\begin{tabular}{|c|c|c|c|}
\hline Antibiotic & $\mathbf{R}$ & I & $\mathbf{S}$ \\
\hline Ampicillin & $\leq 13$ & 14- 16 & $\geq 17$ \\
\hline Bacitracin & $\leq 15$ & $16-17$ & $\geq 18$ \\
\hline Erythromycin & $\leq 13$ & $14-22$ & $\geq 23$ \\
\hline Streptomycin & $\leq 11$ & $12-14$ & $\geq 15$ \\
\hline Tetracycline & $\leq 11$ & $12-14$ & $\geq 15$ \\
\hline
\end{tabular}

\section{Hemolytic activity}

The hemolytic activity of isolates was determined by using blood agar as described by Halder et al (2017).

\section{Animal feeding trial (in vivo study)}

This study was approved by the ethics committee of the Faculty of Veterinary Medicine, Universitas Gadjah Mada, Yogyakarta, Indonesia. A total of 100 broilers (7-day-old, Lohmann strain, average body weight 130 g) were obtained at the research farm of Faculty of Animal Science, Universitas Gadjah Mada, Yogyakarta, Indonesia. Chickens were randomly divided into four groups, $\mathrm{PO}$ as control, $\mathrm{P} 1$ was a daily dose of $10^{7} \mathrm{cfu} / \mathrm{bird}$ L. plantarum BJ3, P2 was daily dose of $10^{7} \mathrm{cfu} / \mathrm{bird}$ Lc. lactis K5, and P3 was a daily dose of $10^{7} \mathrm{cfu} /$ bird L. plantarum BJ3 and Lc. lactis K5. Probiotics supplemented to the chicken orally. Feed and water were provided ad libitum. Chickens are kept in a litter system and the litter changed every week. All of the groups were fed the basal diet which was formulated in Table 2. The basal diets were formulated to the nutrient requirements of the Indonesian National Standard (SNI) for broiler chicken. Data were analyzed using one-way analysis of variance (ANOVA) in RStudio.

\section{Table 2 - Composition and nutrient content of basal diets}

\begin{tabular}{|c|c|c|}
\hline Items & Starter & Finisher \\
\hline \multicolumn{3}{|l|}{ Ingredients (\%) } \\
\hline Corn & 52.0 & 55.0 \\
\hline Rice bran & 8.0 & 10.0 \\
\hline Soy bean meal & 18.0 & 12.0 \\
\hline Meat bone meal & 4.0 & 4.0 \\
\hline Full fat soy bean meal & 16.0 & 17.0 \\
\hline Premix & 1.5 & 1.5 \\
\hline Salt & 0.3 & 0.3 \\
\hline Methionine & 0.2 & 0.2 \\
\hline Total & 100.0 & 100.0 \\
\hline \multicolumn{3}{|l|}{ Nutrient content (calculated) } \\
\hline Metabolism energy (kcal/kg) & 3066.1 & 3113.2 \\
\hline Crude protein (\%) & 21.56 & 19.51 \\
\hline Crude fiber (\%) & 2.72 & 2.81 \\
\hline Extract ether (\%) & 3.77 & 4.02 \\
\hline Methionine (\%) & 0.46 & 0.43 \\
\hline \multicolumn{3}{|l|}{ Analyzed nutrient content (\% DM) } \\
\hline Dry matter & 90.43 & 89.90 \\
\hline Ash & 8.29 & 7.16 \\
\hline Crude protein & 20.07 & 19.84 \\
\hline Extract ether & 4.45 & 4.59 \\
\hline Crude fiber & 6.83 & 5.74 \\
\hline Nitrogen-free extract & 60.36 & 62.67 \\
\hline
\end{tabular}

\section{RESULTS AND DISCUSSION}

\section{Identification and characteristics of LAB}

The characteristic of LAB isolates were shown in Table 3. Variation of pH and bile salt did not affect the growth of LAB. Yamazaki et al. (2012) reported that some of the LAB can grow at pH 2.0, they were L. crispatus CE3, L. crispatus CC4, L. crispatus CC7, L. ingluviei HC2, L. reuteri HC3, L. reuteri HC4, L. vaginalis HE3, L. oris HC6, E. faecium CE1, L. plantarum LQ80, and L. rhamnosus. Adetoye et al. (2018) reported that LAB showed a good growth at variation of pH 3.0, 4.0, 5.0, and 7.0. Same as Aazami et al. (2015) reported that LAB show good growth at pH 2.0 to 5.0. This result was not significantly different with Adetoye et al. (2018) reported that LAB show tolerance of bile salt variations at $0.1 \%$ to $5 \%$. Several previous studies reported that LAB have a tolerance to bile salts of $0.3 \%$ (Silva et al., 2013; Mandal et al., 2015; Kook et al., 2019; and Jomehzadeh et al., 2020). According to Jena et al. (2013) probiotic bacteria are able to survive at $0.15 \%$ to $0.3 \%$ bile salt levels. 
Table 3 - Characteristic of lactic acid bacteria (LAB) isolated from duck excreta

\begin{tabular}{|c|c|c|}
\hline Characteristics & BJ3 & K5 \\
\hline Gram staining & + & + \\
\hline Shape & Rod & Coccus \\
\hline Motility & - & - \\
\hline Catalase & - & - \\
\hline \multicolumn{3}{|l|}{ Growth at temperature $\left({ }^{\circ} \mathrm{C}\right)$} \\
\hline 10 & - & + \\
\hline 35 & + & + \\
\hline 45 & + & + \\
\hline \multicolumn{3}{|l|}{ Growth at pH } \\
\hline 2.0 & + & + \\
\hline 3.0 & + & + \\
\hline 4.0 & + & + \\
\hline 5.0 & + & + \\
\hline \multicolumn{3}{|l|}{ Growth at bile salt $(\% \mathrm{w} / \mathrm{v})$} \\
\hline 0.05 & + & + \\
\hline 0.15 & + & + \\
\hline 0.30 & + & + \\
\hline \multicolumn{3}{|l|}{ Biochemical characteristics } \\
\hline L-Arabinose & + & + \\
\hline Ribose & + & + \\
\hline D-Xylose & + & - \\
\hline Galactose & + & + \\
\hline D-Glucose & + & + \\
\hline D-Fructose & + & + \\
\hline D-Mannose & + & + \\
\hline Mannitol & + & + \\
\hline Sorbitol & + & - \\
\hline Methyl- $\alpha-D-m a n n o p y r a n o s i d e$ & + & - \\
\hline N-Acetylglucosamine & + & + \\
\hline Amygdalin & + & + \\
\hline Arbutin & + & + \\
\hline Esculin & + & + \\
\hline Salicin & + & + \\
\hline Cellobiose & + & + \\
\hline Maltose & + & + \\
\hline Lactose & + & + \\
\hline Melibiose & + & - \\
\hline Saccharose & + & + \\
\hline Trehalose & + & + \\
\hline Melezitose & + & - \\
\hline Amidon & + & - \\
\hline ß-Gentiobiose & + & + \\
\hline D-Turanose & + & - \\
\hline D-Tagatose & + & - \\
\hline Gluconate & + & - \\
\hline
\end{tabular}

The growth ability of LAB at a variety of $\mathrm{pH}$ and bile salt was an important requirement for bacteria as probiotics because the digestive process occurs mechanically and chemically, so probiotic bacteria must be able to survive in acid and alkaline conditions in the digestive tract. According to Stromfová et al. (2004) before the bacteria using as probiotic, it is necessary to carry out several tests to know their potential as probiotic, specifically the origin of the strain, tolerance of acids and bile salts, adhesion to the intestine, production of antibacterial substances and resistance or sensitivity to antibiotics. Resistance of LAB to bile salts is related to carbohydrate metabolism, glycosidase activity, production of exopolysaccharides, and increased adhesion ability. Nurcahyo et al. (2019) stated that LAB tolerance to high bile salt levels is the initial process of metabolism to produce acids that can inhibit the growth of pathogen bacteria. Grampositive bacteria have teichoic acid which functions to maintain ion transport and cell wall integrity, so the bacteria is susceptible to autolysis and be able to maintain external permeability. This was what caused bacteria to survive in the digestive tract.

The LAB was known to ferment carbohydrates into lactic acid. According to Rahman et al. (2016) API 50CHL is used to identify at the species level and to facilitate the metabolic characterization of bacterial strains on various carbohydrate substrates (Muñoz-Quezada et al., 2013). L. plantarum found in duck excreta in this study is also found in chicken excreta. In the study of Robledo-Cardona et al. (2018) Lactobacillus species identified in laying hen excreta are $L$. brevis, $L$. plantarum, L. salivarius, and L. crispatus. In the report of Alhaag et al. (2019), L. plantarum strain HY1 was not shown the ability to ferment inositol. Rahmati (2017) reported that $L$. plantarum can ferment fructose, galactose, glucose, lactose, maltose, melibiose, raffinose, and sucrose. Bhardwaj et al. (2012) reported that L. plantarum can ferment cellobiose, mannitol, mannose, melibiose, raffinose, salicine, sorbitol, sucrose, trehalose, and xylose. The result was different with Kook et al. (2019) reported that L. plantarum is capable of fermenting glycerol, erythritol, D-arabinose, L-arabinose, L- 
xylose, ß-methyl-D-xyloside, rhamnose, dulcitol, inositol, inulin, starch, glycogen, xylitol, D-fucose, L-fucose, D-arabitol, Larabitol, 2 ketogluconate, 5 ketogluconate, $\mathrm{N}$-acetylglucosamine, amygdalin, and arbutin. Lactococcus lactis reported by $\mathrm{Ni}$ et al. (2015) can ferment L-arabinose, ribose, galactose, D-glucose, D-mannose, amygdalin, arbutin, saccharose, trehalose, D-turanose, and gluconate. The ability of LAB species to ferment carbohydrates was not always the same. This is due to several factors such as geographical differences, sample sources, sample preparation, and so on (Rahman et al., 2016). According to Mozzi (2016) LAB are bacteria which can produce lactic acid as the main product. The characteristics of LAB are Gram-positive, non-sporulated, catalase-negative, usually cocci or rods, non-motile, and low Guanidine+Citosine $(G+C)$ content. Lactic acid bacteria classification is based on morphology, glucose fermentation, ability to grow at different temperatures, also tolerance to salt, acid, and alkali. Lactobacillus and Lactococcus are LAB species that are commonly used as probiotics. According to Bintsis (2018) LAB are heterogeneous groups of bacteria and play an important role in the fermentation process such as improving taste, texture, and nutritional value. Bacteriocins and organic compounds produced by LAB play as bioprotective agents in food.

As presented in Table 4, LAB isolated from duck excreta identified 2 genera, Lactobacillus and Lactococcus. Isolate BJ3 was identified as Lactobacillus plantarum (L. plantarum) and isolate K5 was identified as Lactococcus lactis (LC. lactis). This result was confirmed by API $50 \mathrm{CHL}$ and analysis of sequence by $16 \mathrm{~S}$ rRNA. The PCR amplification was carried out using $27 \mathrm{~F}$ and 1492R primers, and the amplicon size was approximately 1000 base pairs (bp) in agarose gel.

Based on phenotypic identification using API $50 \mathrm{CHL}$, isolate BJ3 showed similarity to L. plantarum by $99.9 \%$, and isolate $\mathrm{K} 5$ showed similarity to Lc. lactis ssp. lactis by $91.3 \%$. This result was needed further testing at the molecular level for more accurate results. Comparison of isolate sequences to LAB sequences available on GenBank showed a high similarity of nucleotide identities (97.0 to 100\%). Nevertheless, there were no differences between the results of the molecular identification (by $16 \mathrm{~S}$ rRNA) and phenotypic identification (by API 50CHL).

\section{Table 4 - Identification species lactic acid bacteria based on API 50CHL and 16S rRNA}

\begin{tabular}{lllll} 
Isolates & API 50CHL & \% ID & 16S rRNA & \% ID \\
\hline BJ3 & Lactobacillus plantarum & 99.9 & Lactobacillus plantarum & 100.0 \\
K5 & Lactococcus lactis ssp. Lactis & 91.3 & Lactococcus lactis & 97.0 \\
\hline
\end{tabular}

\section{Enzyme activity}

Bacteria were known to produce enzymes that act in the digestive process. API ZYM was an assay system for the detection of bacterial enzymatic activity. The use of API ZYM could help characterize bacterial species. According to Tiquia (2002) approach with API ZYM aim is to evaluate the enzyme profile. API ZYM consist of control, 3 phosphatase enzymes, 3 esterase enzymes, 3 amino-peptidase enzymes, and 8 glycosyl-hydrolase enzymes. The result of the enzyme activity assay was shown in Table 5. LAB did not show the activity of $\alpha$-chymotrypsin, $\beta$-glucuronidase, $\alpha$-mannosidase, and $\alpha$ fucosidase. This was indicated by the absence of color changes in the enzyme-substrate. The result was not different with Wang et al. (2010), Jena et al. (2013), and Muñoz-Quezada et al. (2013).

\section{Table 5 - Enzyme activity of lactic acid bacteria}

\begin{tabular}{|c|c|c|}
\hline Enzyme profile & BJ3 & K5 \\
\hline \multicolumn{3}{|l|}{ Fosfatase } \\
\hline Alkaline phosphatase & + & + \\
\hline Acid phosphatase & + & + \\
\hline Naphtol-AS-BI- phosphohydrolase & + & + \\
\hline \multicolumn{3}{|l|}{ Esterase } \\
\hline Esterase (C4) & + & + \\
\hline Esterase lipase (C8) & + & + \\
\hline Lipase (C14) & + & + \\
\hline \multicolumn{3}{|l|}{ Amino peptidase } \\
\hline Leucine arylamidase & + & + \\
\hline Valine arylamidase & + & + \\
\hline Cystine arylamidase & + & + \\
\hline \multicolumn{3}{|l|}{ Protease } \\
\hline Trypsin & + & + \\
\hline$\alpha$-chymotrypsin & - & - \\
\hline \multicolumn{3}{|l|}{ Glycosyl hydrolase } \\
\hline$\alpha$-galactosidase & - & - \\
\hline ß-galactosidase & + & + \\
\hline ß-glucuronidase & - & - \\
\hline$\alpha$-glucosidase & + & + \\
\hline ß-glucosidase & + & + \\
\hline N-acetyl-ß-glucosaminidase & + & + \\
\hline$\alpha$-mannosidase & - & - \\
\hline$\alpha$-fucosidase & - & - \\
\hline
\end{tabular}


B-galactosidase is an important enzyme to increase the digestibility of nutrients in the intestine by releasing functional bioactive peptides from proteins such as milk (Burns et al., 2010). The presence of activity on ß-galactosidase indicated that bacteria are able to utilize lactose. In humans, these activities can help reduce lactose intolerance. $\alpha$ galactosidase activity plays an important in hydrolyzing $\alpha$-D-galactosyl-oligosaccharide which is often found in relatively high amounts in breast milk (Muñoz-Quezada et al., 2013). In fermentation, the proteolytic activity of LAB was important because this activity played in flavor improvement. Free amino acids and peptides produced by proteolytic activity have a direct effect on taste or as precursors of aroma-producing compositions through secondary catabolic reactions. Lactobacillus which shows high proteolytic and lipolytic activity is known to be able to significantly lower pH (Rahmati, 2017).

\section{In vitro adhesion}

The adhesion test on intestinal epithelial cells was carried out to determine the attachment ability of LAB to intestinal epithelial cells. This test is carried out to avoid the elimination of LAB during peristaltic in the digestive tract, also as a condition for bacteria to develop and colonize properly (Muñoz-Quezada et al., 2013). As presented in Figure 1, L. plantarum BJ3 and Lc. lactis $\mathrm{K5}$ had the ability to adhere to the broiler intestinal epithelium. When compared with Lactococcus lactis K5, the adhesion ability of L. plantarum BJ3 was more prominent. Wang et al. (2010) reported that probiotic bacteria have the ability to adhere to intestinal epithelial cells. This causes probiotic bacteria to compete with pathogenic bacteria and colonize in the digestive tract.

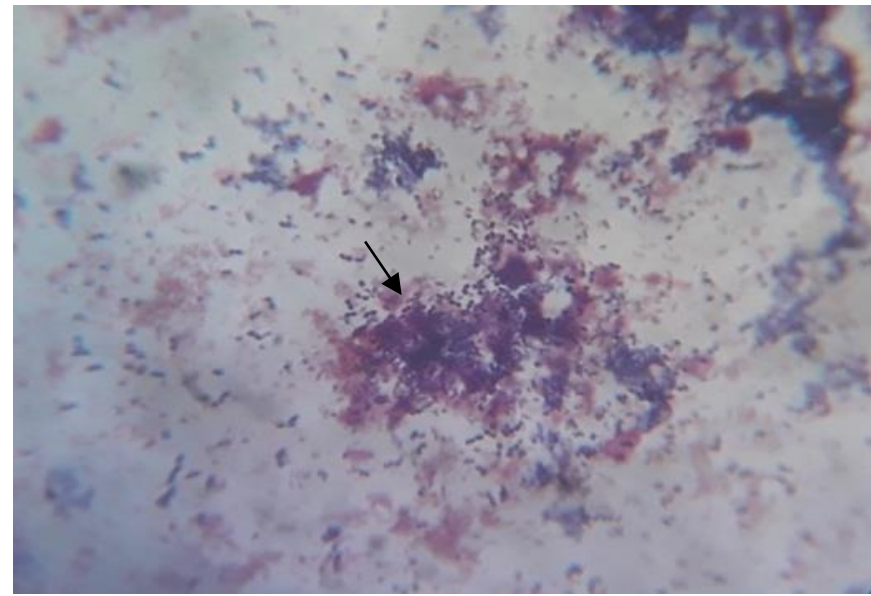

(a)

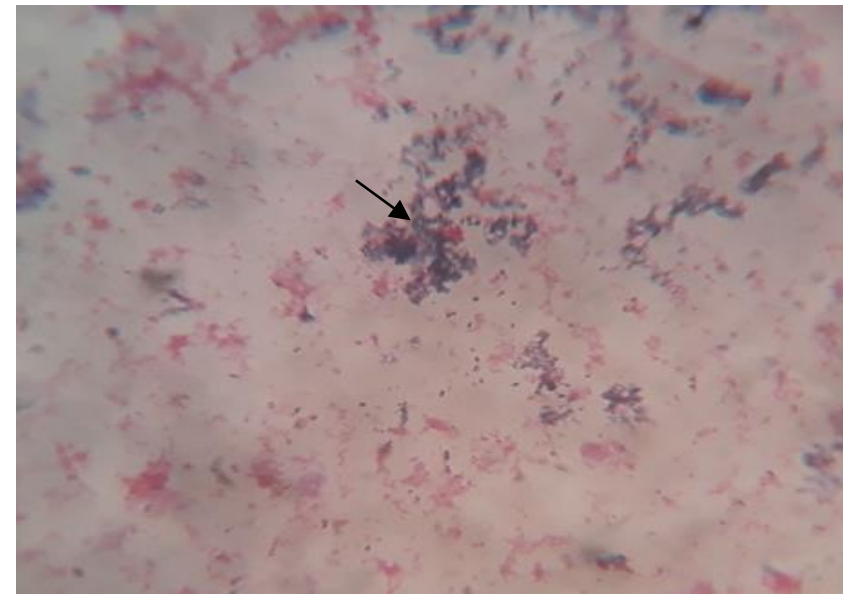

(b)

Figure 1 - Lactic acid bacteria adhesion to intestinal epithelial cells (400x). (a) L. plantarum BJ3; (b) Lc. lactis K5

\section{Antibacterial activity}

The result of the antibacterial activity assay was shown in Figure 2. The size of the inhibition zone differed between LAB and tetracycline antibiotic. The average zone of inhibition of LAB against $E$. coli was $10.0 \mathrm{~mm}$ and tetracycline was $12.00 \mathrm{~mm}$. In the study of Aazami et al. (2015) Lactobacillus has antibacterial activity against $E$. coli, $C$. difficilem $E$. hirea, S. enterica, $P$. aeruginosa, $S$. aureus, and $S$. mutans. The zone of inhibition against $E$. coli is reached $14 \mathrm{~mm}$, while in the study of Rao et al. (2015) is reach between 10 and $17 \mathrm{~mm}$, and Wang et al. (2010) is reach $7 \mathrm{~mm}$. According to Rao et al. (2015) LAB can produce a bacteriocin-like inhibitory substance (BLIS) against pathogen bacteria. Probiotic bacteria produce metabolites as antibacterial such as organic acids, $\mathrm{H}_{2} \mathrm{O}_{2}$, and bacteriocins that affect bacterial metabolism or the production of bacterial toxins (Islam et al., 2016). Based on the results of the antibacterial activity test, LAB could control the problem of infection caused by $E$. coli.

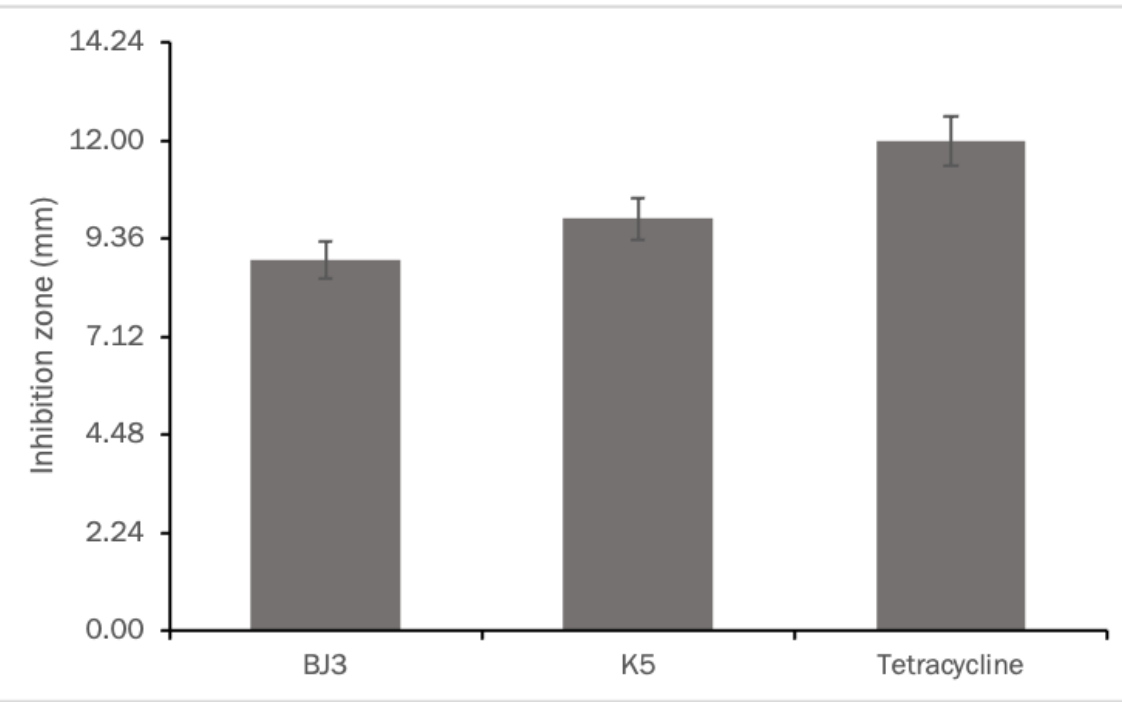

Figure 2 - Antibacterial activity of lactic acid bacteria against $E$. coli 


\section{Antibiotic susceptibility}

Antibiotic resistance test was a safety test of probiotics to provide information in the development of treatment for infections caused by pathogenic bacteria. L. plantarum BJ3 and Lc. lactis K5 were shown a level of sensitivity to some antibiotics of more than $80 \%$ (Table 6). This result was similar to Ludfiani et al. (2020) who reported that LAB isolated from duck and chicken was resistant to streptomycin. In Wang et al. (2010), LAB isolated from human feces and Taiwan pickle resistant to streptomycin, tetracycline, and vancomycin. Present results were different with Adetoye et al. (2018) who stated that LAB isolated from cow feces was sensitive to ampicillin, chloramphenicol, erythromycin, and tetracycline.

\section{Table 6 - Antibiotic resistance of lactic acid bacteria}

\begin{tabular}{|c|c|c|}
\hline Antibiotic & $\begin{array}{ll}\text { Lactic acid bacteria isolates } & \text { BJ3 } \\
\end{array}$ & K5 \\
\hline Ampicillin & $\mathbf{S}$ & S \\
\hline Bacitracin & S & S \\
\hline Erythromycin & S & S \\
\hline Streptomycin & $\mathbf{R}$ & $\mathbf{R}$ \\
\hline Tetracycline & s & s \\
\hline
\end{tabular}

\section{Hemolytic activity}

One of the safety tests for probiotic bacteria was the hemolytic activity test. This was carried out to ensure the bacteria as probiotics were non-pathogenic and safe from virulence factors. The result showed that LAB did not form a hemolytic zone ( $\mathrm{y}$-hemolysis) around the bacterial colony, meaning that LAB was safe from virulence factors and nonpathogenic. Similar results were also reported by Rao et al. (2015), and Adetoye et al. (2018), LAB did not show hemolytic activity on blood agar media.

\section{Animal feeding (in vivo study)}

The cumulative Feed Intake (FI), Body Weight Gain (BWG), and Feed Conversion Ratio (FCR) during the experimental period (21d) are present in Table 7. Supplementation of probiotics were effective to reduce cumulative $\mathrm{FI}(\mathrm{p}<0.05)$. Single-strain and multi-strain supplementation had not any different effects on BWG and FCR. In the study of Ramlucken et al. (2020) supplementation multi-strain has an effect on the growth performance of broilers. Harimurti et al. (2010) reported that single-strain and multi-strain probiotics supplementation show an effect on body weight and FCR. Similar to the study done by Reuben et al. (2021), the supplementation of multi-strain showed significant effects on body weight and FCR.

\section{Table 7 - Effect of supplementation of probiotics on broiler performance}

\begin{tabular}{lcccc} 
Treatment & FI (g/bird) & BWG (g/bird) & FCR & Mortality (\%) \\
\hline P0 & 1328.20 & 801.07 & 1.66 & 0 \\
P1 & 1311.82 & 817.23 & 1.61 & 0 \\
P2 & 1277.85 & 796.52 & 1.61 & 0 \\
P3 & 1302.75 & 792.82 & 1.67 & 0 \\
SEM & 8.378 & 13.748 & 0.030 & - \\
p-value & 0.031 & 0.772 & 0.710 & - \\
\hline
\end{tabular}

$\mathrm{FI}=$ feed intake; $\mathrm{BWG}=$ body weight gain; $F C R=$ feed conversion ratio.

\section{CONCLUSION}

Lactobacillus plantarum BJ3 and Lactococcus lactis $\mathrm{K} 5$ isolated from duck excreta in Bantul had potential as probiotics for chicken nutrition, which was proven the probiotic properties of both based on in vitro study and showed supplementation of both as orally affected growth performance of broilers (reduced $\mathrm{FI}$ ) on in vivo study. Further studies are required to determine the effect single or multi-strain of both on carcass and meat quality, immunity, disease treatment, nutrient digestibility, microbial shedding, excreta odor contents, and more.

\section{DECLARATIONS}

\section{Corresponding Author}

E-mail: wied_as@ugm.ac.id

\section{Authors' Contribution}

Ludfiani DD, Asmara W, Wahyuni AETH, Aastuti P contribute to the research and on writing up of the manuscript. Putri MThK, Ridwan NF contribute to molecular analysis. 


\section{Conflict of interests}

The authors have not declared any conflict of interest.

\section{Acknowledgments}

This study was funded by the Directorate General of Higher Education Ministry of Education and Culture Republic of Indonesia through the PMDSU program.

\section{REFERENCES}

Aazami N, Kalantar E, Poormazaheri H, Pour NSV, and Jouzan GS (2015). Selection and characterization of potential probiotic Lactobacilli spp. isolated from chicken feces may be used as a potent antibacterial agent. Asian Journal of Dairy and Food Research, 35(1): 50-57. Link ; DOI

Abd El-Hack ME, El-Saadony MT, Shafi ME, Qattan SY, Batiha GE, Khafaga AF, and Alagawany M (2020). Probiotics in poultry feed: A comprehensive review. Journal of Animal Physiology and Animal Nutrition, 104(6): 1835-1850. Link; DOI

Adetoye A, Pinloche E, Adeniyi BA, and Ayeni FA (2018). Characterization and anti-salmonella activities of lactic acid bacteria isolated from cattle faeces. BMC microbiology, 18(96): 1-11. Link ; DOI

Alhaag H, Yuan X, Mala A, Bai J, and Shao T (2019). Fermentation Characteristics of Lactobacillus Plantarum and Pediococcus Species Isolated from Sweet Sorghum Silage and Their Application as Silage Inoculants. Applied Sciences, 9: 1-17. Link ; DOI

Amaliah ZZN, Bahri S, and Amelia P (2018). Isolasi dan karakterisasi bakteri asam laktat dari limbah cair rendaman kacang kedelai [Isolation and characterization of lactic acid bacteria from soybean soaking wastewater]. Jurnal Fitofarmaka Indonesia, 5(1): 253-257. Link ; DOI

Bhardwaj A, Puniya M, Sangu KPS, Kumar S, Dhewa T (2012). Isolation and biochemical characterization of Lactobacillus species isolated from dahi. A Journal of Dairy Science and Technology, 1(2): 1-14. Link ; Google Scholar

Bintsis T (2018). Lactic acid bacteria: their applications in foods. Journal of Bacteriology and Mycology, 6(2): 89-94. Link ; DOI

Brashears MM, Jaroni D, and Trimble J (2003). Isolation, selection, and characterization of lactic acid bacteria for a competitive exclusion product to reduce shedding of Escherichia coli 0157:H7 in cattle. Journal of Food Protection, 66(3): 355-363. Link ; DOI

Burns P, Sánchez B, Vinderola G, Ruas-Madiedo P, Ruiz L, Margolles A, Reinheimer J, and Reyes-Gavilán CG (2010). Inside the adaptation process of Lactobacillus delbrueckii subsp. lactis to bile. International Journal of Food Microbiology, 142: 132-141. Link ; DOI

CLSI (Clinical and Laboratory Standards Institute) (2015). Performance Standards for Antimicrobial susceptibility Testing: Twenty-Fifth Informational Supplement. CLSI document M100-S25. Wayne, PA. Link

Ding S, Yan W, Ma Y, and Fang J (2020). The impact of probiotics on gut health via alternation of immune status of monogastric animals. Animal Nutrition, 7(1): 24-30. Link ; DOI

Fuller R (1975). Nature of the determinant responsible for the adhesion of Lactobacili to chicken crop epithelial cells. Journal of General Microbiology, 87(2): 245-250. Link ; DOI

Garcia-Gonzalez N, Battista N, Prete R, and Corsetti A. (2021). Health-Promoting Role of Lactiplantibacillus plantarum Isolated from Fermented Foods. Microorganisms, 9(2): 349. Link ; DOI

Garriga M, Pascual M, Monfort JM, and Hugas M (1998). Selection of Lactobacilli for chicken probiotic adjuncts. Journal of Applied Microbiology, 84: 125-132. Link; DOI

Gilliland SE, Nelson CR, and Maxwell C (1985). Assimilation of cholesterol by Lactobacillus acidophilus. Applied and Environmental Microbiology, 49(2): 377-381. Link ; DOI

Goswami G, Bora SS, Parveen A, Boro RC, and Barooah M (2017). Identification and functional properties of dominant lactic acid bacteria isolated from Kahudi, a traditional rapeseed fermented food product of Assam, India. Journal of Ethnic Foods, 4(3): 187-197. Link ; DOI

Halder D, Mandal M, Chatterjee SS, Pal NK, and Mandal S (2017). Indigenous probiotic Lactobacillus isolates presenting antibiotic like activity against human pathogenic bacteria. Biomedicines, 5(31): 1-11. Link ; DOI

Han HY, Zhang KY, Ding XM, Bai SP, Luo YH, Wang JP, and Zeng QF (2017). Effect of dietary fiber levels on performance, gizzard development, intestinal morphology, and nutrient utilization in meat ducks from 1 to 21 days of age. Poultry science, 96(12): 4333-4341. Link ; DOI

Harimurti S, Nasroedin, Rahayu ES, and Kurniasih (2010). Effect of indigenous lactic acid bacteria probiotics on broiler performance. The $5^{\text {th }}$ International Seminar on Tropical Animal Production, October 19-22, 2010, Yogyakarta, Indonesia. Link

Huang J, Zhang W, Hu Z, Liu Z, Du T, Dai Y, and Xiong T (2020). Isolation, characterization and selection of potential probiotic lactic acid bacteria from feces of wild boar, native pig and commercial pig. Livestock Science, 237: 104036. Link ; DOI

Ibrahim D, Abdelfattah-Hassan A, Arisha AH, Abd El-Aziz RM, Sherief WR, Adil SH, and Metwally AE (2020). Impact of feeding anaerobically fermented feed supplemented with acidifiers on its quality and growth performance, intestinal villi and enteric pathogens of Mulard ducks. Livestock Science, 242:104299. Link ; DOI

Islam KN, Akbar T, Akther F, and Islam NN (2016). Characterization and confirmation of Lactobacillus spp. from selective regional yoghurts for probiotic and interference with pathogenic bacterial growth. Asian Journal of Biological Sciences, 9 (1-2): 1-9. Link ; DOI

Jena PK, Trivedi D, Thakore K, Chaudhary H, Giri SS, and Seshadari S (2013). Isolation and characterization of probiotic properties of Lactobacilli isolated from rat fecal microbiota. Microbiology and Immunology, 57: 407-416. Link ; DOI

Jomehzadeh N, Javaherizadeh H, Amin M, Saki M, Al-Ouqaili MTS, Hamidi H, Seyedmahmoudi M, and Gorjian Z (2020). Isolation and identification of potential probiotic Lactobacillus species from feces of infants in southwest Iran. International Journal of Infectious Diseases, 96: 524-530. Link ; DOI

Ludfiani DD, Asmara W, Wahyuni AETH, Astuti P (2020). Antibiotic susceptibility of lactic acid bacteria isolated from duck and Jawa Super chicken excreta intended for use as probiotic. Veterinary Practicioner, 21(2): 165-167. Link

Karakas-sen A and Karakas E (2018). Isolation, identification and technological properties of lactic acid bacteria from raw cow milk. Bioscience Journal, 34(2): 385-399. Link ; DOI

Karimi S, Rashidian E, Birjandi M, and Mahmoodnia L (2018). Antagonistic effect of isolated probiotic bacteria from natural sources against intestinal Escherichia coli pathotypes. Electronic Physician, 10(3): 6534-6539. Link ; DOI

Kook S, Chung E, Lee Y, Lee DW, and Kim S (2019). Isolation and characterization of five novel probiotic strains from Korean infant and children faeces. PLoS ONE, 14(10): 1-17. Link ; DOI

Mandal H, Jariwala R, and Bagchi T (2015). Isolation and characterization of lactobacilli from human faeces and indigenous fermented foods for their potential application as probiotics. Canadian Journal of Microbiology, 62(4): 349-359. Link ; DOI

Mozzi F (2016). Lactic acid bacteria. Encyclopedia of Food and Health, p. 501-508. Link ; DOI

Muñoz-Quezada S, Chenoll E, Vieites JM, Genovés S, Maldonado J, Bermúdez-Brito M, Gomez-Llorente C, Matencio E, Bernal MJ, Romero F, Suáres A, Ramón D, and Gil A (2013). Isolation, identification and characterisation of three novel probiotic strains (Lactobacillus 
paracasei CNCM I-4034, Bifidobacterium breve CNCM I-4035 and Lactobacillus rhamnosus CNCM I-4036) from the faeces of exclusively breast-fed infants. British Journal of Nutrition, 109(S2): S51-S62. Link ; DOI

Ni K, Wang Y, Li D, Cai Y, and Pang H. (2015). Characterization, identification and application of lactic acid bacteria isolated from forage paddy rice silage. PLoS ONE, 10 (3): 1-14. Link ; DOI

Nurhikmayani, Daryono RRS, and Retnaningrum E (2019). Isolation and molecular identification of antimicrobial-producing lactic acid bacteria from Chao, South Sulawesi (Indonesia) fermented fish product. Biodiversitas, 20(4): 1063-1068. Link ; DOI

Nurcahyo H, Suyanta, Dale A, Furqon FA. (2019). Isolation and characterization of lactic acid bacteria (LAB) from small intestine content of duck (Anas Sp.) as a probiotic candidate. Journal of Physics: Conference Series, 1397: 1-9. Link ; DOI

Rahman MM, Hossain KM, and Rahman SMM (2016). Isolation, characterization, and properties study of probiotic lactic acid bacteria of selected yoghurt from Bangladesh. African Journal of Microbiology Research, 10(1): 23-31. Link ; DOI

Rahmati F (2017). Characterization of Lactobacillus, Bacillus and Saccharomyces isolated from Iranian traditional dairy products for potential sources of starter cultures. AIMS Microbiology, 3(4): 815-825. Link ; DOI

Ramlucken U, Ramchuran So, Moonsamy G, Lalloo R, Thantsha MS, and Rensburg CJ (2020). A novel Bacillus based multi-strain probiotic improves growth performance and intestinal properties of Clostridium perfingens challenged broilers. Poultry Science, 99: 331-341. Link ; DOI

Rao KP, Chennappa G, Suraj U, Nagaraja H, Raj APC, Sreenivasa MY (2015). Probiotic potential of Lactobacillus strains isolated from sorghumbased traditional fermented food. Probiotics and Antimicrobial Protein, 7: 146-156. Link ; DOI

Reuben, RC, Sarkar SL, Ibnat H, Setu MAA, Roy PC, and Jahid IK (2021). Novel multi-strain probiotics reduces Pasteurella multocida induced fowl cholera mortality in broilers, Scientific Reports, 11: 1-16. Link ; DOI

Robledo-Cardona S, Ramírez-Hincapié S, and Correa-Álvarez J. (2018). Robledo-Cardona, S., S. Ramírez-Hincapie, dan J. Correa-Álvarez. 2018. Implementation of a Non-Invasive Bioprospecting Protocol for Isolation of Lactobacillus from Feces of Hens Under Foraging Conditions. Ingeniería y Ciencia, 14 (28): 93-111. Link; DOI

Silva BC, Jung LRC, Sandes SHC, Alvim LB, Bomfim MRQ, Nicoli JR, Neumann E, and Nunes AC (2013). In vitro assessment of functional properties of lactic acid bacteria isolated from faecal microbiota of healthy dogs for potential use as probiotics. Benefical Microbes, $4(3)$ : 267-75. Link; DOI

Stromfová V, Lauková A, and Ouwehand AC (2004). Selection of enterococci for potential canine probiotic additives. Veterinary Microbiology, 100(1-2): 107-114. Link ; DOI

Śliżewska K, Markowiak-Kopeć P, Sip A, Lipiński K, and Mazur-Kuśnirek M (2020). The effect of using new synbiotics on the turkey performance, the intestinal microbiota and the fecal enzymes activity in turkeys fed ochratoxin a contaminated feed. Toxins. 12(9): 578. Link ; DOI

Thakkar P, Modi HA, and Prajapati JB (2015). Isolation, characterization and safety assessment of lactic acid bacterial isolated from fermented food products. International Journal of Current Microbiology and Applied Sciences, 4(4): 713-725. Link

Tiquia SM (2002). Evolution of extracellular enzyme activities during manure composting. Journal of Applied Microbiology, 92: 764-775. Link ; DOI

Wang C, Lin P, Ng C, and Shyu Y (2010). Probiotic properties of Lactobacillus strains isolated from the feces of breast-fed infants and Taiwanese pickled cabbage. Anaerobe, 16(6): 578-585. Link ; DOI

Yadav S, and Jha R (2019). Strategies to modulate the intestinal microbiota and their effects on nutrient utilization, performance, and health of poultry. Journal of Animal Science and Biotechnology, 10(1): 1-11. Link ; DOI

Yamazaki DM, Ohtsu H, Yakabe Y, Kishima M, and Abe H (2012). In vitro screening of Lactobacilli isolated from chicken excreta to control Salmonella enteritidis and Typhimurium. British Poultry Science. 53(2): 183-189. Link ; DOI

Zitvogel L, Daillère R, Roberti MP, Routy B, and Kroemer G (2017). Anticancer effects of the microbiome and its products. Nature Reviews Microbiology, 15(8): 465-478. Link ; DOI 